\title{
The Proteolytic Enzyme of Nepenthes (II).
}

\author{
BY
}

\section{S. H. VINES.}

I N the Annals of Botany for December, 1897, I published 1 a paper on this subject, in which I adduced a considerable amount of evidence to prove that, contrary to the opinions of Dubois and Tischutkin, the pitcher-liquid of Nepenthes contains a proteolytic enzyme. Since writing that paper I have continued my observations, of which I now give some account by way of supplement.

\section{Activity of Pitcher-Liquid.}

I have nothing to add that would in any way modify my assertion that I have never failed to obtain digestion of fibrin by the liquid in a relatively short time, provided that the liquid was duly acidified. My new observations refer to the effect of exposure to high temperatures, of treatment with alkalies, and of filtration of the liquid, upon its digestive activity.

Heat. The following results will serve to illustrate the general effect of exposure to high temperatures. The method of experiment was to maintain the liquid for a given time at the required temperature, and then to institute a digestionexperiment, adding fibrin and the necessary acid; in nearly

[Annals of Botany, Vol. XII. No. XLVIII. December, 1898.] 
every case there was a control digestion-experiment with unheated liquids :-

(March I, '98.) Liquid heated to $70-80^{\circ} \mathrm{C}$, for 15 minutes: digestion of fibrin $(.05 \mathrm{grm}$.) not complete in 5 hours, though it eventually took place; control-experiment, digestion complete in $2 \frac{3}{4}$ hours.

(March 3.) Liquid gradually heated from $60^{\circ}-80^{\circ} \mathrm{C}$, maintained at $80^{\circ} \mathrm{C}$. for 5 minutes, then allowed to cool: total time of exposure to heat, I 5 minutes; digestion not complete in 5 hours, but within 20 hours; control, digestion complete within 2 hours.

(March 8.) Liquid maintained at $80^{\circ}$ C. for $15-20$ minutes: digestion not complete until morning of the fourth day (March II); control, digestion complete within 3 hours. In a subsequent experiment (May I 7) the effect of treating the liquid to $80^{\circ} \mathrm{C}$. for 20 minutes was less marked: in this case the time required by ro $\mathrm{cc}$. of the liquid to digest $.05 \mathrm{grm}$. of glycerin-fibrin was just 24 hours.

(March I5.) Liquid maintained at $78-83^{\circ}$ C. for 30 minutes: digestion díd not take place, although the experiment was continued for 4 days; in the control, digestion was complete in $\mathbf{I} \frac{1}{2}$ hour. In a subsequent experiment (March 19 ) I found that liquid which had been kept at $80^{\circ} \mathrm{C}$. for $3 \circ$ minutes gave no indication of digestive action on fibrin although the experiment was prolonged for a week; it may be fairly concluded that the digestive power had been entirely destroyed. In the control, digestion was complete within 5 hours.

With regard to the action of a boiling temperature $\left(100^{\circ} \mathrm{C}\right.$.), I was surprised to find, on several occasions, that liquid boiled for some seconds did not lose its digestive power, though the rate of digestion was made very much slower. It seems, in fact, that to entirely destroy digestive power, the liquid must be kept at $100^{\circ} \mathrm{C}$. for an appreciable time, say 3-5 minutes.

Alkali. I have confined myself to the investigation of the action of sodium carbonate $\left(\mathrm{Na}_{2} \mathrm{CO}_{3}\right)$ upon the digestive activity of the liquid. The method of experiment was to add to a quantity (usually 5 or Io cc.) of the pitcher-liquid an amount of the solid salt requisite to produce the desired degree of alkalinity: the alkaline liquid was then placed in the incubator, and maintained for any required time at any 
given temperature. After this treatment the liquid was neutralized, then acidified with $\mathrm{HCl}$, and a digestion-experiment was made.

At an early stage it became apparent that the results of such experiments are dependent upon the three following factors:-(I) the degree of alkalinity; (2) the duration of the period of alkalinity; (3) the temperature maintained during the period of alkalinity.

I took as a starting-point the statement made in my paper of last year (p. 572), that the digestive activity of the liquid is destroyed by treatment with $5 \% \mathrm{Na}_{2} \mathrm{CO}_{3}$ for 3 hours at a temperature of $35-40^{\circ} \mathrm{C}$. I found, on repeating the experiment and prolonging it, that this conclusion is not accurate. In the original experiment the time allowed for digestion was $16 \frac{1}{2}$ hours, and in that period, it is true, no trace of digestive action could be detected: but in a subsequent experiment with a longer digestive period, evident signs of digestion were apparent in 20 hours, and digestion was completed in about 26 hours.

The following is a summary of the principal experiments made :-

I. Temperature during period of alkalinity, $35-38^{\circ} \mathrm{C}$.

Treatment with $0.5 \% \mathrm{Na}_{2} \mathrm{CO}_{3}$ for 30 minutes; retards digestion.

$$
\begin{aligned}
& , 1 \% \quad, \quad, 2 \frac{1}{2} \text { hours; about doubles time of } \\
& \text { digestion. } \\
& , \quad, \mathbf{1} \% \quad, \quad, \quad \text { I } 7 \quad, \quad \text { digestion much retarded. }
\end{aligned}
$$

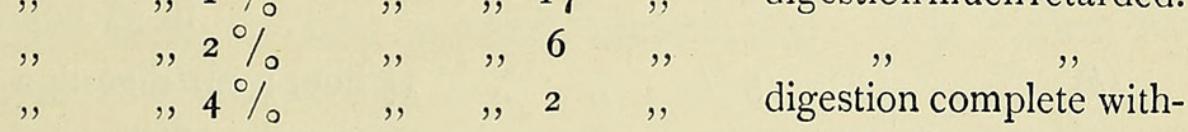

$$
\begin{aligned}
& \text { " " } 4 \% \quad, \quad 2 \quad, \quad \text { igestion comple } \\
& , \quad, 5 \% \quad, \quad,, \quad \text { I } \quad, \quad \text { digestion complete with- } \\
& \text {, , } 5 \% \quad, \quad, \quad 3 \quad, \quad \text { digestion complete with- } \\
& \text { in } 6 \text { hours. } \\
& \text { in } 26 \text { hours. }
\end{aligned}
$$

It will be observed that, in all the foregoing experiments, digestion, though often much retarded, eventually took place. It still remained to ascertain under what conditions total destruction of digestive power could be effected by treatment 
with $\mathrm{Na}_{2} \mathrm{CO}_{3}$. In view of the great retardation of digestion caused by treatment with $5 \% \mathrm{Na}_{2} \mathrm{CO}_{3}$ indicated in the foregoing table, I determined to experiment especially with this degree of alkalinity, but at a higher temperature: the temperature upon which I fixed was $50^{\circ} \mathrm{C}$. The following are illustrative experiments :-

\section{Temperature during period of alkalinity, $50^{\circ} \mathrm{C}$.}

(May 30.) Treatment with $5 \% \mathrm{Na}_{2} \mathrm{CO}_{3}$ for 45 min.; digestion much retarded.

(June ז.)

, $\mathbf{I} \frac{1}{2}$ hour ; no digestion in 48 hours.

Hence it would appear that, in the second case, the digestive power had been totally destroyed.

The following are some further comparative experiments to determine more closely the degree and duration of alkalinity, at $50^{\circ} \mathrm{C}$., necessary to destroy digestive action. In each case there was a control-tube, the liquid in which was heated to $50^{\circ} \mathrm{C}$. for the same length of time as the others, but was not treated with $\mathrm{Na}_{2} \mathrm{CO}_{3}$, though diluted subsequently to the same extent as the others: the amount of fibrin used in the digestion was . or grm.

(a) Treatment with $5 \% \mathrm{Na}_{2} \mathrm{CO}_{3}$ for $\mathrm{I} \frac{1}{2}$ hour; no digestion in 6 days. digestion complete in 4 days.

control ; digestion complete in $3 \frac{1}{2}$ hours.

(b) " $, 5 \%, \quad, \quad \mathrm{I} \frac{1}{2}$ hour; no digestion in 5 days.

$, \quad, \quad \mathbf{1} \%, \quad, \quad, \quad$ no digestion in 5 days.

control ; digestion complete in a few hours.

(c) , , $\quad$ I $\%, \quad, \quad, \quad \mathbf{I}$ hour ; no digestion in 4 days.

control ; digestion complete in a few hours. 
On comparing the results of $a, b$, and $c$, it would appear that treatment with $\mathrm{I} \% \mathrm{Na}_{2} \mathrm{CO}_{3}$ for one hour at a temperature of $50^{\circ} \mathrm{C}$. is an approximate index to the stability of the enzyme.

Filtration. It occurred to me that some light might be thrown upon the bacterial explanation of the digestive activity of the pitcher-liquid by experiments with liquid which had passed through a Berkefeldt-filter. I found that liquid which has passed through such a filter has lost its acid reaction and its colouration. It still retains some digestive power, but is far less active than unfiltered liquid, the period of digestion being more than doubled.

This result might be made use of by the supporters of the bacterial explanation, as affording some sort of evidence in favour of that view; but even so, it would be far from conclusive. However, in order to test the value of this evidence I instituted some experiments with regard to the effect of filtration through the Berkefeldt-filter upon liquids containing pepsin and ptyalin. With regard to pepsin, I found that an unfiltered solution of glycerin-extract of pig's stomach digested $.05 \mathrm{grm}$. of fibrin in a quarter of an hour, whilst an equal quantity of the same solution after filtration required nearly $5^{\frac{1}{2}}$ hours to digest the same weight of fibrin. Similarly some diluted saliva caused the complete conversion of a small quantity of starch into sugar within a few minutes, whereas starch treated with filtered dilute of saliva continued to give more or less marked blue-reaction with iodine for four or five hours.

It is clear that solutions of pepsin and of ptyalin are affected by the Berkefeldt-filter in much the same way as is the pitcher-liquid of Nepenthes. If it be argued that the diminished activity of filtered pitcher-liquid is due to the removal of Bacteria, the same argument must equally apply to the solutions of pepsin and of ptyalin; but I do not think that any one would venture at present to attribute the action of gastric juice or of saliva to the presence of Bacteria. The obvious conclusion to be drawn from these experiments is 
that enzymes are retained in a marked degree by the Berkefeldt-filter.

\section{The ZyMogen.}

In my previous paper (p. 578) I stated that I had not succeeded in successfully repeating the experiments of $1877^{1}$, which demonstrated the presence of a zymogen in the glandular tissue of the pitcher. The method which I adopted in 1877 was as follows: some pitchers were treated with dilute acetic acid $(1 \%)$ for 24 hours previously to the preparation of the glycerin-extract ; comparative experiments between the glycerin-extracts prepared from pitchers so treated and the glycerin-extract prepared from pitchers gathered at the same time, but not treated with acid, showed that in every case the digestive power of the former was much greater than that of the latter, as indicated by the greater rapidity of digestion. In one experiment the acidextract dissolved fibrin in 6 hours, whilst fibrin put to digest with the ordinary extract was but slightly attacked in that time. During the present year I have made some experiments with results confirmatory of those of 1877 . They are as follows :-

June 2, '98. Took two unopened pitchers of $N$. Mastersiana; opened and washed out the pitchers ; the pitcher-liquid strongly acid; cut up the glandular portions of the pitchers into small pieces; the whole weighed $8 \mathrm{grm}$.; divided into two halves $A$ and $B ; A$ was rubbed up in a mortar with $20 \mathrm{cc}$. distilled water; $B$ was rubbed up in a mortar with $20 \mathrm{cc}$. of $.25 \%$ solution of $\mathrm{HCl}$; both $A$ and $B$ were then placed for 45 minutes in the incubator at $50^{\circ} \mathrm{C}$.; the liquid was then poured off from each, the substance dried somewhat with blotting-paper, and then rubbed up each with $20 \mathrm{cc}$. glycerin, to prepare glycerin-extracts $A$ and $B$, and left to stand.

On June io the digestion-experiment was made: $5 \mathrm{cc}$. of each of the extracts were taken, and placed in a tube with $5 \mathrm{cc}$. of $.4 \%$ $\mathrm{HCl}$, together with $.0 \mathrm{rgrm}$. of fibrin; the tubes were put into the incubator (temperature about $37^{\circ} \mathrm{C}$.) at 10.30 a.m. By 6.30 p.m. the fibrin in tube $B$ (acid-extract) was completely digested, whereas 
that in tube $A$ (neutral extract) did not disappear until over 48 hours later.

In another experiment of about the same date, in which, however, the pitcher-substance was treated with $.5 \%$ acetic acid for about 24 hours at ordinary temperature (about $\mathrm{I}_{5}{ }^{\circ} \mathrm{C}$.), the acid-extract digested more rapidly than the neutral, but the difference was not so marked as in the preceding case.

July 2 I, ' 98 . Took two pitchers, one unopened, the other recently opened; cut up small; material divided into three parts of $2.7 \mathrm{grm}$. each: (I) was rubbed up at once with $20 \mathrm{cc}$. glycerin; (2) with $20 \mathrm{cc}$. of $.25 \% \mathrm{HCl}$; and (3) with $20 \mathrm{cc}$. distilled water: (2) and (3) were placed in an incubator at $36^{\circ} \mathrm{C}$. and were kept there till next day ( $18-20$ hours), the liquid was filtered off from them, and they were each rubbed up with $20 \mathrm{cc}$. glycerin.

On Aug. 2 the digestion-experiment was made: Io cc. of each extract were strained off through muslin; to each were added Io cc. of $\cdot 4 \% \mathrm{HCl}$, together with $0 \mathrm{I} \mathrm{grm}$. fibrin, and all three were placed in the incubator (temperature $36^{\circ} \mathrm{C}$.) to digest at ro. 3 o a.m. At 5 p.m. the fibrin in tube (2) (acid-extract) showed signs of digestion, and was almost entirely dissolved by 5 p.m. on the following day. The fibrin in tube (3) had all undergone solution by the evening of Aug. 5, whereas that in tube (I) still showed no sign of digestion.

A second digestion-experiment with the same extracts was made on Aug. 30, with essentially similar results, though the period of digestion was longer. The experiment commenced at I0. I 5 a.m., and at 5 p.m. no indication of digestion could be seen in any one of the three tubes. Next morning (Aug. 3I) at 9 a.m. the fibrin in tube (2) (acid-extract) was seen to be attacked; the process of digestion continued slowly in this tube until it was complete (night of Sept. 2); the fibrin in the two tubes (I) and (3) underwent no perceptible change in this time.

The foregoing results suffice to show that, under certain circumstances, previous treatment with acid causes the glands of the pitcher to yield a more active glycerin-extract, or to yield an active extract when otherwise the extract would be inactive; and it can only be concluded that this must be due to the presence of a zymogen in the glands from which the enzyme is liberated on treatment with acid. However, I must 
admit that, as pointed out in my paper of last year, I have by no means always succeeded in obtaining a more active extract as the result of treatment with acid; on the contrary, I have frequently found that previous treatment of the pitchers with acid diminished instead of increasing the activity of the glycerin-extract. I do not regard these apparent contradictions as wholly attributable to various conditions of the pitchers, for I have obtained sometimes quite opposite results with pitchers as nearly as possible of the same age, and sometimes quite similar results with pitchers of different ages (e.g. opened and unopened). On the contrary, my results seem to show that the differences in the activity presented by the various acid-extracts are due rather to the mode of treatment of the pitcher-material. It would appear that the most effectual mode of decomposing the zymogen is to act upon the tissue with acid for a short time at a relatively high temperature (see example of June 2-10). More prolonged treatment at a lower temperature (say $35^{\circ} \mathrm{C}$.) would seem to cause not only the liberation of the enzyme, but also its extraction from the glands in connexion with the digestion of the pitcher-tissue itself.

I may just point out in conclusion that the marked acidity of the liquid in the unopened pitcher is no doubt to be connected with its high digestive activity; whilst the acid is useless for digestive purposes until the opening of the pitcher, it is probably of importance in that it acts upon the zymogen, liberating the enzyme.

\section{The Products of Digestion.}

In my paper of last year I pointed out that the chief proteid product of digestion was a substance closely resembling deutero-albumose, and I stated further that I had failed to detect the presence of a true peptone, that is, of a proteid which is not precipitated on saturation with ammonium sulphate. I have, however, since detected the presence of peptone, though in relatively small quantity, among the products of the digestion of fibrin by the pitcher-liquid. 
The clue to the matter was found on this wise. The method which I had followed (see my paper of Dec. '97, p. 579) in examining the products of digestion involved the precipitation of these substances by filtration into excess of alcohol. Whilst investigating the nature of the ultimate products, I evaporated a considerable quantity of the alcohol which had been used for precipitation, and this left a dark brown syrupy residue. Some of this residue, dissolved in a small quantity of distilled water, formed a brownish solution, giving no precipitate on boiling, but good xanthoproteic and biuret reactions. A portion of this solution was put to saturate with ammonium sulphate and gave a dense precipitate which brought down with it all the colouring-matter; the clear, colourless liquid obtained on filtration still gave strong xanthoproteic reaction, and continued to do so after continued saturation for two days longer. Another portion of the brown solution was put to dialyze, and within twenty-four hours the dialysate gave strong xanthoproteic reaction; on saturating the dialysate with ammonium sulphate, there was a precipitate, the filtrate from which still gave the xanthoproteic reaction, and continued to do so on further saturation. These observations indicated the presence of peptone without, however, absolutely establishing it; for it might be the case that the precipitation of the deutero-albumose by means of ammonium sulphate had been incomplete, and that the proteid reactions were due to this substance rather than to peptone.

It became necessary, therefore, to employ some method by which the separation of deutero-albumose and peptone could be certainly effected. Fortunately I applied for advice to Mr. Ramsden, Fellow of Pembroke College, who has an intimate knowledge of the chemistry of proteids, and he kindly directed me to a paper by Kühne ${ }^{1}$ on this very point. Kühne's method consists in saturating the neutralized digestion-liquid with ammonium sulphate when boiling. After

${ }^{1}$ Zeitschrift für Biologie, 1892 (Erfahrungen üb. Albumose und Pepton). It may be asserted that, until the appearance of this paper, no true peptone had been obtained free from albumose. 
cooling and filtering, the liquid is again heated and made alkaline with ammonia, and is then again saturated with ammonium sulphate. It is once more cooled and filtered, then boiled to drive off the ammonia, again saturated with ammonium sulphate whilst boiling, and made acid with acetic acid. The excess of ammonium sulphate is then got rid of by adding alcohol to the liquid; most of the ammonium sulphate is precipitated, and the supernatant liquid holds in solution whatever peptone is present, which may be ultimately obtained by repeated treatment with alcohol and decantation of the supernatant liquid.

With this method at my disposal, I had no difficulty in demonstrating the presence of peptone in the digestion-liquids, though it was necessary to concentrate these liquids before proceeding to test them. Mr. Ramsden also found peptone in a quantity of digestion-products precipitated by alcohol, which he was good enough to examine for me.

I have nothing to add with regard to the other products of digestion, beyond the fact that I have been able to confirm my statement that leucin is one of them .

\section{Conclusion.}

I. The experiments relating to the action of high temperatures and of alkalies upon the enzyme confirm the statement made in my paper of last year with regard to its great stability; in fact, it would appear that it is the most stable of all known proteolytic enzymes. Whilst its activity can easily be much diminished by exposure to high temperature or treatment with an alkali, it still retains a sort of residual digestive power which asserts itself in very slow and prolonged digestion, and which can only be destroyed by relatively strong measures.

2. It may, I think, be fairly concluded from the facts given in this paper, in conjunction with those which I published in 1877 , that the enzyme is derived from a zymogen present in the gland-cells. 
3. The discovery of true peptone among the products of digestion facilitates the classification of the enzyme. Green ${ }^{1}$ has found that the proteolytic ferment present in germinating seeds acts in an acid medium, producing a relatively large quantity of albumose together with peptone, leucin, and tyrosin; that it is in fact a tryptic ferment, differing mainly from the trypsin of the pancreatic juice in requiring an acid medium for its digestive action. In all these respects (though I have not made out the production of tyrosin) the proteolytic enzyme of Nepenthes-pitcher closely resembles that of the germinating seed; but it is much more rapid and energetic in its action, and apparently more stable in its nature. These two proteolytic enzymes are distinguished, by their activity in an acid medium, from those, such as papaïn ${ }^{2}$ and the enzyme in the fruit of Cucumis utilissimus ${ }^{3}$, which are most active in a faintly alkaline medium. It is a remarkable fact that, whatever may be the reaction of the medium in which they can work, all these enzymes are essentially tryptic in their mode of action; in fact it is not improbable that this may be a characteristic feature of all vegetable proteolytic enzymes whatsoever.

1 Phil. Trans., I887.

${ }^{2}$ See Martin, in Journ. of Physiol., V, I884, and VI, I 885.

${ }^{3}$ See Green, in Annals of Botany, VI, 1892. 


\section{$2 \mathrm{BHL}$ Biodiversity Heritage Library}

Vines, Sydney Howard. 1898. "The proteolytic enzyme of Nepenthes (II)." Annals of botany 12, 545-555.

https://doi.org/10.1093/oxfordjournals.aob.a088707.

View This Item Online: https://www.biodiversitylibrary.org/item/233102

DOI: https://doi.org/10.1093/oxfordjournals.aob.a088707

Permalink: https://www.biodiversitylibrary.org/partpdf/318519

\section{Holding Institution}

Smithsonian Libraries

\section{Sponsored by}

Biodiversity Heritage Library

\section{Copyright \& Reuse}

Copyright Status: Not in copyright. The BHL knows of no copyright restrictions on this item.

This document was created from content at the Biodiversity Heritage Library, the world's largest open access digital library for biodiversity literature and archives. Visit BHL at https://www.biodiversitylibrary.org. 